\title{
Ilomata International Journal of Social Science
}

P-ISSN: 2714-898X; E-ISSN: 2714-8998

Volume 3, Issue 1 January 2022

Page No. 97-116

\section{The Effect of Public Accountability and Transparency on State Financial Management Mechanism: A Quantitative Method Analysis}

\author{
Alian Natision ${ }^{1}$, Eddy Bruno Esien ${ }^{2}$, Dwikora Harjo ${ }^{3}$, \\ Redjeki Agoestyowati ${ }^{4}$, Putri Ayu Lestari ${ }^{5}$ \\ ${ }^{134}$ Institut Ilmu Sosial dan Manajemen STIAMI, Indonesia \\ ${ }^{2}$ Charles University, Czech Republic \\ ${ }^{5}$ Sekolah Tinggi Ilmu Ekonomi YAI, Indonesia \\ Correspondent: $\underline{\text { aliannatision07@gmail.com }}{ }^{1}$
}

$\begin{array}{ll}\text { Received } & \text { : August 26, } 2021 \\ \text { Accepted } & \text { : January 15, } 2022 \\ \text { Published } & \text { : January 31, } 2022\end{array}$

Citation: Natision, A., Esien, E, B., Harjo, D., Agoestyowati, E., Lestari, P, A (2022). The Effect of Public Accountability and Transparency on State Financial Management Mechanism: A Quantitative Method Analysis. Ilomata International Journal of Social Science, 3(1), 97-116.

https://doi.org/10.52728/ijss.v3i1.433

\begin{abstract}
Since public sector reform initiatives, public accountability and transparency have advanced democracy and good governance on managing state finances. State financial management mechanism involves regional policies and fiscal decentralization trend in the devolution of responsibility for empowerment from central to local units of governments, but the governance face challenges to effectively manage and control the use of public funds that best meet citizen's needs. This study determines the effect of public accountability and transparency on the management of state finances in Indonesia, as well as the extent to which public accountability and transparency affect the management of state finances. Based on a descriptive quantitative case-oriented research approach, 60 survey interviews are collected and analyzed with multiple linear regression analysis techniques. This study concludes that Public Accountability partially has a significant effect on the Financial Management Mechanism. On the other hand, partially public transparency has no significant effect on the State Financial Management Mechanism. Cumulatively, some aspects of Public Accountability and Transparency have a significant effect on the State Financial Management Mechanism. If unaccountability in decentralise administrative model prevails, problem of ineffective policy output may persist to impair sustainable finance and public values for good governance in times of covid-19 crisis related society.
\end{abstract}

Keywords: Indonesia, Management Mechanism, Public Accountability, Public Transparency, Management Mechanism, State Finance 


\section{INTRODUCTION}

The Indonesian nation is currently in the process of democratic transition since the Reformation era, which has made the democratic atmosphere very dynamic, with very complex problems due to regional political and economic changes, through the struggle for control over several natural resources which are increasingly limited in number. Amid these dynamic economic and political conditions, the community needs certainty that what they provide to the state is managed properly. The demand for public accountability and public transparency from the community to state managers has become a growing phenomenon. The performance of state managers has been under the spotlight when people began to question the value they get for the taxes and levies they incur. Monetary decentralization from the national government to regional state run administrations, because of local independence, has prompted huge changes in the monetary administration components of the national government and regional legislatures. The public is now increasingly aware that they have the right to know the accountability and transparency of all processes in the state financial management mechanism.

Monetary Management incorporates arranging, execution, organization, announcing, responsibility, and oversight of state accounts (Varga et al., 2021). A good state financial management mechanism is very important for the continuity of national development (Pinha \& Sagawa, 2020). Reliable Management of state finances is influenced by public accountability and public transparency, that have transformative and empowering potential putting information in the hands of people (de Renzio, 2015), to observe government performance (Esien, 2019a, 2020a, 2020b). Public accountability is the government's obligation to account for all public resource management and activity reports. Meanwhile, public transparency is openness in earnest and based on the principle that the public has the right to know and should have access to detailed information about how governments use resources (de Renzio, 2015). These two things have a long history and become the most observed part by the community, namely the provision of transparent information how government use public resources. As far back as $350 \mathrm{BC}$, Aristotle's The Politics suggested that “... to protect the Treasury from being defrauded, let all money be issued openly in front of the whole city, and let copies of the accounts be deposited in various wards" (de Renzio, 2015). In addition, The Declaration of the Rights of Man and of the Citizen, a fundamental document of the French Revolution of 1789, also recognized citizen's rights to know their taxes are spent and to request an account of any public bureaucrats. This opportunity appeal for state financial managers to prove their ability to implement the principles of accountability and transparency for fiscal discipline, managing risks, and reducing corruption opportunities (de Renzio, 2015; Esien, 2020a, 2021). Reliable financial management is financial Management that is accountable and transparent with openness to the wider community that range from international organizations to civil society groups and from private foundations to sector-specific initiatives (de Renzio, 2015).

Moreover, accountability characterized a type of commitment that represent the achievement or disappointment of executing the association's main goal to accomplish foreordained objectives and destinations, which are conveyed through the media and carried out periodically (Mardiasmo, 2018). In this case, the adaptation of public value accountability indicates an important institution and performance management tool in the implementation of state financial 
management (Esien, 2020a, 2020b, 2019b). Regarding the fact that the existence or existence of a country depends on its people's perspectives and awareness. Therefore, governments are obliged to give an accountable and transparent report of their performance management of state finances. Moreover, Public Accountability in Road Map Bureaucratic Reform orders following 3 (three) principle focuses of administrative change: (1) a perfect and responsible organization; (2) viable and effective administration, and (3) administration that has quality public administrations (European Commission, 2017; M. Robinson, 2015). Similarly, accountability is the vanguard towards good governance (de Renzio, 2015), about how government agencies can account for the best Management of state finances. In this case, the change in the mindset and culture-set of the administration of the bureaucracy, which was originally work-oriented (output) to performance-oriented (outcome), emphasizes the concept of public accountability and transparency in organizational culture for state finance management (Alom, 2021; Desselle et al., 2018; M. Robinson, 2015).

Recent events indicate that accountability and transparency still tend to be formal and function as a „lip-service." (Adensamer et al., 2021; Ismail \& Clarke, 2014). For instance, pandemic demand a strong state response but the civil society's important role in holding officials accountable has been minimized (Keevill, 2020). Similarly, another example shows Indonesia's government non-disclosure of covid-19 data that infringe data transparency (Ayuningtyas et al., 2021). Although there is progress with the enforcement of public control through mass and social media, abuse of authority and power, collusion, corruption, and nepotism remain in the society (Martini, 2012). Similarly, lack of enforcement at the local level is one of the main problems with negative impact on fiscal decentralization (Martini, 2012), and management of state finance. Moreover, these law enforcement institutions suffer from limited financial and human resources, political interference, and vulnerability to bribery among others. In fact, the situation tends to get worse due to the reduced authority of Indonesian Corruption Eradication Commission $(\mathrm{KPK})$ in the investigation, investigation process, and at the local level that enforce weak accountability mechanism. For example, the emergence of the National Insight Test (TWK) case for KPK employees as a condition for changing status to State Civil Apparatus (ASN) succeeded in getting rid of senior KPK employees who had high integrity against efforts corruption Eradication.

Since the revision of the KPK Law, there have been more and more cases of misappropriation of state finances in Indonesia that are not immediately resolved by law enforcement. The Indonesian Anti-Corruption Society (MAKI) filed a pretrial lawsuit for five corruption cases that were deemed to have no clear continuation, namely the Century Bank case, the E-KTP case (electronic ID card), the Social Assistance Food Service case from the Ministry of Social Affairs, the AW-101 Helicopter Procurement case, and the development of the Malang Regent's corruption case (VOI Editorial Team, 2021). Meanwhile, the Indonesian Corruption Watch (ICW) recorded only 13 cases out of 120 cases that the KPK completed in 2020 (VOI Editorial Team, 2021). "These five lawsuits were filed as an effort to restore the Anti-Corruption Perception Index which decreased in 2020 to 37 from the previous 40 years (2019)", said Boyamin (seen in VOI Editorial Team, 2021). This decline in the ranking was partly triggered by efforts to weaken the authority of the KPK through the revision of the KPK Law, the 
controversy over the KPK leadership who issued many controversial policies such as the appointment of former corruptors as survivors of corruption, and many pending cases handled by the KPK. The results of this ranking are certainly a setback in law enforcement efforts against perpetrators of corruption as an extraordinary crime. The law seems to be slow, dull, and regulated by the holders of power and owners of capital (oligarchy). Nevertheless, to build accountability the enforcement of laws, guidelines, and measures needs to be just and upright. Moreover, multi stakeholders- that include academics, mass media and civil society etc.- strict supervision should take place to hold actors and institution accountable in public policy implementation (Esien, 2019b).

Therefore, public accountability and transparency mechanism of state financial management are significant performance managerial tools in government and all interested agencies' good governance mode under (fiscal) decentralization process (Esien, 2020a, 2021, 2019b). In addition, the idea of accountability in good administration manifest in industrialized and emerging economies., including Indonesia. The World Bank, for instance, emphasizes six good administrations to accountability and transparency in public sector financial management. These include (a) voice and responsibility; (b) political soundness and nonattendance of savagery; (c) government viability; (d) administrative quality; (e) law and order; and (f) control of debasement (Kaufmann et al., 2003). This indicates that accountability may be one of the most important indicators in good governance and sustainable development (Esien, 2019a). Moreover, the World Bank employ voice and accountability, which deciphered as open voice or public cooperation to expand accountability. In this case, accountability requires public investment to deliver better open strategies. Furthermore, accountability is a form of accountability to whom and for what it is accounted for. This accountability is the obligation of the trust holder (the government) to give accountability to the party who gives the trust (the people). In other words, accountability is related to government performance that can be accounted for public participation (Khotami, 2017).

Regarding state financial management mechanism, the government can implement two types of public participation, which are dynamic public support and inactive public cooperation. Dynamic public cooperation relates to public contribution, which affect public approach plan process for the creation of open arrangements and as per the local area's goals. Simultaneously, latent public interest is investment where the local area executes an arrangement that the public authority has chosen. IAP2 (International Association for Public Participation), for instance, has a range of public interest utilized worldwide in numerous nations (Alizar \& Usman, 2020). IAP2 forms five degrees of public participation, namely the lowest are informed (inform the community), increase to consult (consultation with the community), then involve (involving the community), then collaborate (collaborating with the community). The highest is empowered (empowering the community in the formulation of public policies). Considering, the state financial management mechanism, these five ranges of public investment can be utilized independently to guarantee local area inclusion, both in dynamic public interest (strategic plan) and detached public cooperation (strategic execution). What is vital to note is that public support is a fundamental piece of public accountability and transparency. In this case, the higher the public participationactive and passive- the more accountable is the state financial management mechanism. As a 
matter of fact, the government efforts show high accountability in all aspects such as policy accountability, budget accountability, data/information accountability, and accountability in law enforcement. Then again, public investment is likewise firmly connected with analysis from the local area. Notwithstanding, analysis of the public authority ought to be made in a decent and right manner. In particular, the analysis in view of logical information that is a type of public investment. However, the society and especially researchers are expected to stay quiet and offer their contribution to the public authority that avoid government disappointment.

As a matter of fact, public accountability positively influences financial management mechanisms if there is honesty and compliance with state financial management applicable laws and regulations. This can be seen from the stages of state financial management that involve all related elements because the financial management process is continuously accountable to higher authorities. Especially, to prioritize the attitude of professionalism applied through those who manage finances. In addition, the work program compiled is a quality program. This program is structured to achieve the organization's vision, mission, and goals and the wider community. Furthermore, it is also supported through the level of education possessed by financial managers and training related to financial governance, most of which have been attended by financial managers.

Great public transparency will reinforce government responsibility, good administration, and authenticity in different organizational setting. This creates public authenticity for the public authority. Likewise, transparency help to increment public trust and re-establish citizens' trust with bureaucrats. However, bureaucrats' often lack public transparency because of public administrators' negligence actions to give the require residents' data (Chatzivgeri et al., 2020). As a matter of fact, this diminishes the degree of public trust and confidence in the public authority (S. C. Robinson, 2020). According to Araujo and Tejedo-Romero (2016), this current review's transparency idea depends on organization hypothesis and authenticity hypothesis (Araujo \& Tejedo-Romero, 2016). Organization hypothesis alludes to an office relationship which is an agreement between at least one entertainer (administrators) giving a command to different entertainers (specialists) to make a move or authority in the interest of bosses (Jensen and Smith, 1985 ) in principal-agent's corporative agreement decision making process (Esien, 2019a). Office hypothesis or office hypothesis of corporate administration was proposed by Alchian and Demsetz (1972) and Jensen and Meckling (1976). They argue that firms exemplify progression of legally binding connections between people (Low \& Ho, 2016). Yet, traditional financial aspects consider the firm as a solitary item element to boost benefit (Carías Vega \& Keenan, 2016). In Learmount (2004) view, organizations can be depicted as agreements and again haggled by various people trying to amplify their benefits . Moreover, office hypothesis clarifies the conduct of an organization according to the viewpoint of different agreements between different gatherings. Investors who contribute assets for the organization to work, for instance, are not viewed as organization proprietors, but as corporate daring people. Organization chiefs get assets from financial backers who accept that administrators can utilize reserves proficiently and viably to produce benefits for the organization. Administrators sign agreements that recognize their exercises and decide how benefits are distributed among supervisors and financial backers. Since 
The Effect of Public Accountability and Transparency on State Financial Management Mechanism: A

it is extremely challenging to depict and anticipate potential fates, contracts endorsed by supervisors are hard to authorize.

As a matter of fact, Jensen, and Meckling (1976) recognized three organization costs for corporate pioneers to screen specialist conduct (Elgebeily et al., 2021). This includes checking the board, restricting specialists to directors, and lingering misfortunes (Rahaman, 2014). In Fligstein and Freeland (1995) opinion, the most productive agreement to direct the head and specialist unsettle the organization hypothesis (Shnayder et al., 2016). Likewise, this agreement development represents the focal point of organization hypothesis (Gonçalves et al., 2019). In this case, the agreement needs to incorporate the specialist's obligations, rewards, and the business' privileges. This is to screen the specialist's presentation. Furthermore, regulative conduct bonding (Esien, 2019a) and results-situated agreements are the two principle of performance monitoring. Conduct arranged agreements involve pay as the essential award for specialists. Interestingly, different prizes are given to specialists under outcomes situated agreements like commissions, investment opportunities, and move of property freedoms. The agreement decision to compensate specialists indicate the basic measures to settle office problems. Subsequently, administrators have the choice to settle dispute according to the agreements. In addition, human beings that include bureaucrats are bounded rational and opportunist in their action/behaviour to pursue self-interest instead of organization interests and objectives (Esien, 2019b). On the other hand, office hypothesis depicts supervisors as specialists and investors as entertainers. This hypothesis contends that firm worth can't be augmented assuming proper motivating forces or satisfactory checking are not adequately successful to control firm administrators from utilizing their carefulness to augment their benefits.

Regarding authenticity, this method adjusts discernments or suspicions that an activity made by a substance is a move that is alluring, suitable, or as per a socially evolved arrangement of standards, qualities, convictions, and definitions. This authenticity is significant for the public authority and organizations. Since local area authenticity is vital for future turns of events. In Suchman (1995) opinion, the authenticity hypothesis is the insight or supposition that the ideal activity is suitable or proper in a framework based on standards, qualities, convictions, and social definitions. In addition, the authenticity hypothesis depends on the thought of the common agreement suggested between friendly organizations and society. Moreover, the hypothesis requires foundations to accomplish objectives in accordance with the desires of the more extensive local area. In Dark et al. (1996) view, authenticity is "a frameworks situated perspective on the association and society ... grants us to zero on the job of data and divulgence in the connection between associations, the State, people, and gatherings.". The definition implies that authenticity is an organization with executive's framework that is arranged towards favouring one side with the local area, individual government, and local gatherings. Hence, as a framework that focuses on the arrangements or interests of the local area. The organization's tasks should measure up to the assumptions of the local area.

In fact, that authenticity can be acquired when there is a match between the organization's presence that doesn't middle or is as per the presence of the current worth framework in the public arena and the climate (Nielsen et al., 2021). At the point when there is a shift towards non-conformance, the organization's authenticity can be undermined. The reasoning for this 
The Effect of Public Accountability and Transparency on State Financial Management Mechanism: A

hypothesis is that an association or organization exist with the assumption that society understands that the association works for a worth framework equivalent with the local area's worth framework. Moreover, authenticity hypothesis urges organizations to guarantee their exercises and execution to society. Organizations use their yearly reports to show the impression of natural obligation for local area acknowledges. This acknowledgment expands the worth of the organization to build organization benefits. This can support or help financial backers to settle speculation on choices.

Carroll and Bucholtz (2003) express that the improvement of society's level of mindfulness and human advancement opens potential doors for expanding requests for natural wellbeing mindfulness (Benites-Lazaro et al., 2018). It is additionally expressed that the organization's authenticity according to partners can be done with the uprightness of the execution of morals in business and expanding corporate social obligation (Monfort et al, 2021). Corporate social obligation has advantages to further develop the organization's notoriety, keep up with the organization's picture and procedure (Wibisono, 2017). Local area authenticity is an essential variable for the organization to foster the organization later (Kesberg \& Keller, 2021). This can be utilized as a vehicle to develop its system, particularly connected with endeavours to situate itself during an undeniably progressed society (Lysova et al., 2019).

Hierarchical authenticity should be visible as something that organizations need or look for from society. Subsequently, authenticity is an advantage or expected asset for organizations to get by. Lindblom (1994) states that an association might apply four authenticity methodologies when confronted with different authenticity dangers. Subsequently, to manage the disappointment of the organization's presentation, the initiative will attempt to instruct its partners about the association's objectives to further develop its exhibition, attempt to change the partner's view of an occasion (yet don't change the real presentation of the association), redirect (control) consideration from the issue of concern (focusing on some sure action disconnected to disappointments) and attempting to change outer assumptions regarding its presentation.

Authenticity hypothesis in its overall structure gives a significant understanding into the act of corporate social obligation divulgence. The greater part of the major corporate social obligation exposure drives can be followed to at least one of the authenticity techniques proposed by Lindblom. For instance, there is an overall inclination for corporate social obligation divulgences to accentuate positive focuses for authoritative conduct contrasted with negative components.

In the public authority viewpoint, authenticity hypothesis is a hypothetical point of view inside the structure of financial and political hypothesis. Meyer and Scott (2009) depict authenticity as the base of similarity among government and society's way of life. Authenticity can be considered adjusting discernments or suppositions that activities taken by the public authority are alluring, fitting, or as per socially created frameworks of standards, qualities, convictions, and definitions (Suchman, 1995). Parties give authenticity outside the public authority, however the public authority itself might control authenticity. This shows that the progressions in friendly qualities and standards become an inspiration for changes in government associations and a wellspring of tension for government authenticity (O' Donovan, 2002). 
Therefore, the government as a policymaker must identify stakeholders, where community groups that have a large influence can interfere with the policy process if their expectations are not met; the policy will be taken based on the expectations of these stakeholders. However, there will be a legitimacy gap when there is a misalignment between government programs and stakeholder expectations. Neu et al. (1998) argue that to reduce this gap, the government should identify the activities under its control and identify groups of people who have the political and economic power to provide legitimacy to the government. This makes the government must know how to respond to various interest groups to legitimize government policies. Thus, legitimacy can be said to be a condition for a government to maintain its power (Hanifa et al., 2005). Furthermore, legitimacy is the process of how a government institution tries to obtain, maintain, and improve the organization's image in the eyes of its stakeholders. Legitimacy management depends on communication between the government and stakeholders (Samkin and Schneifer, 2010). This communication is not limited to traditional communication through the media but includes meaningful actions and non-verbal displays. When carrying out the legitimacy process, use strategies by forming positive government opinions in the eyes of stakeholders. (Suchman, 1995)

In other words, communication becomes an important channel to gain legitimacy from stakeholders. The government can use four legitimacy strategies when it encounters a threat of legitimacy, namely by trying to convince stakeholders through education and information about the suitability of the organization's actions rather than changing the actions or policies that have been taken or can also be done by justifying stakeholders about the goals (Morgan et al., 2021). Or the organization's intention to improve its performance through organizational change, change the organization's perception without changing the organization's actual performance, divert attention from important issues to other related issues through a symbolic approach to manipulate stakeholder perceptions, and change external expectations about organizational performance ( $\underline{\text { Sawandi \& Thomson, 2014). }}$.

The four strategies can be carried out by disclosing performance information to the public, such as disclosure in the annual report. The government can disclose information that can strengthen its legitimacy, for example, by mentioning awards that have been worn or savings programs that have been successfully implemented to gain legitimacy from stakeholders (Parsa et al., 2018). It is hoped that disclosing the institution's achievements and clarifying and refuting negative news that may appear in the media. The goal of efforts to gain legitimacy from the community is to support the institution's main goals. Furthermore, this legitimacy will improve the institution's reputation, which in turn will affect the positive value of the institution (Deegan \& Islam, 2014).

Suppose agency theory and legitimacy theory are applied in government institutions. In that case, it can be assumed that the government's failure to implement a policy is caused by several conditions, including one of which is the low legitimacy of the community towards policies issued by the government. Therefore, public transparency is very important to be implemented by the government to ensure that the state financial management mechanism runs well and is effective at all levels. 
Public accountability and transparency mechanism to manage state finances in Indonesia still face obstacles, challenges, threats, and disturbances from various parties interested in enriching themselves by stealing state money through corrupt practices, collusion, and nepotism. The practice of public accountability and transparency in Indonesia is still a mere formality and modesty. Meanwhile, the public needs more substantial, honest, and candid reports on the results of public accountability. Likewise, the transparency system was developed to support public accountability. Public transparency that is practiced still tends only to meet the requirements of financial statements and get the title of Unqualified (WTP) from the Supreme Audit Agency (BPK). Still, essentially it is not able to prevent budget leakage through existing state financial mechanisms. Public accountability is a sufficient condition, while transparency and public participation are necessary conditions. This means that public accountability implementation depends on the aspects of transparency and public participation are implemented properly, especially in the mechanism of state financial management in Indonesia.

The purpose of this study is to examine the effect of public accountability and transparency on the Management of state finances in Indonesia and and to what extent public accountability and transparency affect the Management of state finances. The operational theory used in this research is the theory of Accountability Indicators from Shafritz \& Russel (1997), namely (1) The process of making a decision that is made in writing, available to citizens and meets applicable administrative standards; (2) Accuracy and completeness of information related to ways to achieve the goals of a program; (3) Clarity of the objectives to be achieved; (4) Feasibility and consistency of operational targets; (5) Management information system and results monitoring. Meanwhile, the public transparency aspect uses the concept of public transparency (Araujo \& Tejedo-Romero, 2016), which adopts the agency theory and legitimacy theory from Suchman (1995). The level of transparency of government finances is measured by the amount of information available in the financial statements of government institutions. This involves disclosing financial information and access to that information by stakeholders (Araujo \& Tejedo-Romero, 2016), which consists of either mandatory disclosure or voluntary disclosure (Ryan et al., 2002). The paper begins with section two discussing the method of this study. In section three the authors of this paper present the result and discussions. Finally, this paper ends with a conclusion.

\section{METHOD}

The design of this study is from a descriptive quantitative research approach. The methodology has several advantages as it attempts to collect information and statistically analyse it (VOXCO.com, 2022). Moreover, this design relies on the assumptions that an uncomplicated description is desire that focus on the details of what, where, when, and why of an event or experience to understand a particular context (Holly, 2014). In this study, the population is the State Civil Apparatus (ASN) - executor of Indonesia governmental and development duties(Sarnawa, 2018) who ensure the integrity, cohesiveness, and unity of the State Civil Apparatus. Similarly, ASN is involve in the planning process of the state financial system with many as 70 people that is relevant for this research. This approach determines the research sample using the Krejcie and Morgan formula: $n=\frac{N}{N d^{2}+1}$ to select a sample from within a general population 
The Effect of Public Accountability and Transparency on State Financial Management Mechanism: A

(Krejcie \& Morgan, 1970, 2017). This simplify process determine the sample size for the finite population so that the number of research respondents was 59.34 or rounded up to 60 people. The data collection technique used in this research is a survey method to determine insights about a group of State Civil Apparatus (ASN) group of administrators through the distribution of standardized questionnaires in inquiring data (Smart Survey, 2022). The measurement scale used is a Likert scale and the transformation of ordinal data to intervals. The independent variables in this study consist of public accountability $\left(\mathrm{X}_{1}\right)$ and public transparency $\left(\mathrm{X}_{2}\right)$. While the dependent variable in this study is the State Financial Management Mechanism (Y). The opetionalization of the variables of this research are as follows:

a. Public Accountability Variable $\left(\mathrm{X}_{1}\right)$

1. The decision-making process in the financial management mechanism is made in writing.

2. The decision-making process in the financial management mechanism meets the applicable administrative standards.

3. The decision-making process in the financial management mechanism is based on accurate data and information.

4. The decision-making process in the financial management mechanism has clear targets and objectives.

5. The decision-making process in the financial management mechanism is made based on accurate data and information.

6. The decision-making process in the financial management mechanism is made based on the applicable implementation guidelines.

7. The decision-making process in the financial management mechanism is made based on the applicable technical guidelines.

8. The decision-making process in the financial management mechanism is based on a feasibility study conducted previously.

9. The decision-making process in the financial management mechanism is made consistently with the objectives to be achieved.

10. The decision-making process in the financial management mechanism considers the evaluation results from previous implementations.

11. The decision-making process in the financial management mechanism does not repeat the mistakes that occurred from the previous implementation.

12. The decision-making process in the financial management mechanism uses a centralized monitoring system.

13. The decision-making process in the financial management mechanism is made according to a predetermined budget.

14. The decision-making process in the overall financial management mechanism is reported accurately.

15. The decision-making process in the financial management mechanism undergoes an independent audit process.

b. Public Transparency Variable $\left(\mathrm{X}_{2}\right)$

1. The decision-making process in the financial management mechanism is open to the public.

2. The decision-making process in the financial management mechanism involves stakeholders. 
The Effect of Public Accountability and Transparency on State Financial Management Mechanism: A

3. The decision-making process in the financial management mechanism is monitored by the public.

4. The decision-making process in the financial management mechanism is communicated to stakeholders.

5. The decision-making process in the financial management mechanism is socialized to stakeholders.

6. The decision-making process in the financial management mechanism is reported regularly.

7. The decision-making process in the financial management mechanism is reported to the public.

8. The decision-making process in the financial management mechanism is evaluated by the public.

9. The decision-making process in the financial management mechanism prioritizes the public interest.

10. The decision-making process in the financial management mechanism considers input from stakeholders.

11. The decision-making process in the financial management mechanism is audited independently.

12. The decision-making process in the financial management mechanism considers aspects of public information transparency.

13. The decision-making process in the financial management mechanism aims to increase public legitimacy.

14. The decision-making process in the financial management mechanism aims to increase public trust.

15. The decision-making process in the financial management mechanism always meets public expectations.

c. State Financial Management Mechanism Variable (Y)

1. The decision-making process in the financial management mechanism is made through a careful planning process

2. The decision-making process in the financial management mechanism is made in a systematic and detailed manner.

3. The decision-making process in the financial management mechanism is made based on the Work Plan and Budget of the State Ministries/Agencies.

4. The decision-making process in the financial management mechanism is made based on Government Regulation Number 20 of 2004 concerning Government Work Plans

5. The decision-making process in the financial management mechanism is made based on Government Regulation No. 21 of 2004 concerning RKA-KL (Act of the Republic of Indonesia Number 1 of 2004, 2004)

6. The decision-making process in the financial management mechanism is made by considering the aspects of implementing a budgeting approach with a medium-term prospective

7. The decision-making process in the financial management mechanism is made by considering the aspects of implementing integrated budgeting.

8. The decision-making process in the financial management mechanism is made by considering the aspects of implementing performance-based budgeting. 
The Effect of Public Accountability and Transparency on State Financial Management Mechanism: A

9. The decision-making process in the financial management mechanism ensures the linkage between the planning and budgeting processes

10. The decision-making process in the financial management mechanism is prepared based on input from the parliament.

11. The decision-making process in the financial management mechanism is approved by parliament

12. The decision-making process in the financial management mechanism is based on realistic revenue projections

13. The decision-making process in the financial management mechanism is made based on the basic assumptions of macroeconomic conditions

14. The decision-making process in the financial management mechanism is supervised by BPK

15. The decision-making process in the financial management mechanism is reported to BPK

16. The decision-making process in the financial management mechanism is audited by BPK

17. The decision-making process in the financial management mechanism is reported to parliament

18. The decision-making process in the financial management mechanism is supervised by the KPK

19. The decision-making process in the financial management mechanism is evaluated periodically

20. The decision-making process in the financial management mechanism is public information

The design of data analysis in this study aims to obtain detailed research results and the results are as expected by the researcher. In addition, the test of hypothesis is important in this study to express the relationships and significant between variables and prediction on the results of the research questions and / or hypothesis (Salkind, 2017). Data processing take place throughout several stages. Namely, through editing data, grouping data, tabulating data, and calculating scores (Jansen \& Warren, 2020). The data is analysed through multiple linear regression (MLR) statistical analysis technique that uses several explanatory variables to predict the outcome of a response variable (Hayes, 2022). Data processing is carry out through the Statistical Package for Social Sciences (SPSS) application software to undertake a range of statistical procedures (Noels, 2018).

The major and minor hypotheses of this study are as follows:

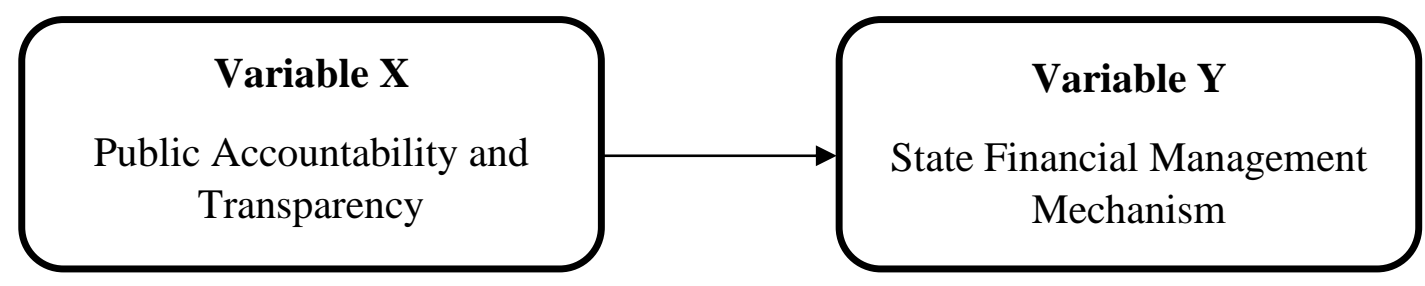

Figure 1. Major Hypothesis

$\mathbf{H}_{0} \quad$ : Public Accountability and Transparency have no significant effect on the State Financial Management Mechanism.

$\mathbf{H}_{1} \quad$ : Public Accountability and Transparency have a significant effect on the State Financial Management Mechanism. 


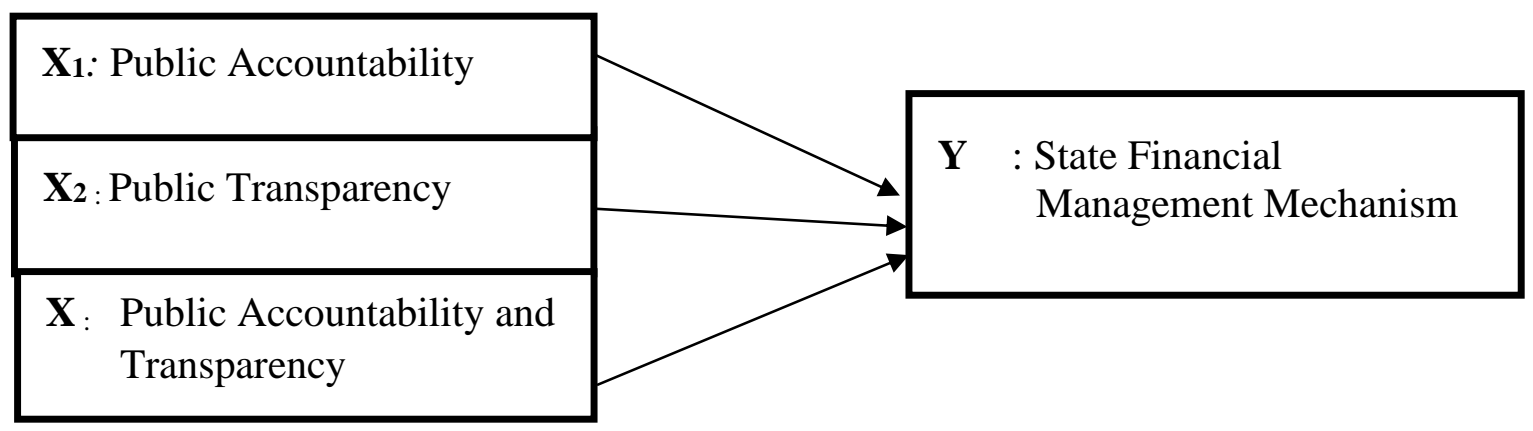

Figure. 2. Hypothesis Minor

1. $\mathbf{H}_{0}$ : Public Accountability has no significant effect on the State Financial Management Mechanism.

$\mathbf{H}_{1}$ : Public Accountability has a significant effect on the State Financial Management Mechanism..

2. $\mathbf{H}_{0}$ : Public Transparency has no significant effect on the State Financial Management Mechanism.

$\mathbf{H}_{1}$ : Public Transparency has a significant effect on the State Financial Management Mechanism.

3. $\mathbf{H}_{0}$ : Public Accountability and Transparency have no significant effect on the State Financial Management Mechanism.

$\mathbf{H}_{1}$ : Public Accountability and Transparency have a significant effect on the State Financial Management Mechanism.

\section{RESULTS AND DISCUSSION}

\section{Partial t Test}

Multiple linear regression analysis is a direct connection between at least two free factors and the reliant variable (Hayes, 2022). This research is to decide the heading of the connection between the free factor and the reliant variable is emphatically or contrarily related and to foresee the worth of the reliant variable if the free variable increments or diminishes. The fractional $t$-test in different straight relapse is planned to test whether the boundaries (relapse coefficients and constants) that are anticipated to assess the numerous direct relapse condition/model are the right boundaries or not. The specific importance here is that the boundary can clarify the conduct of the autonomous variable in affecting the reliant variable. Boundaries assessed in straight relapse incorporate block (steady) and slant (coefficient in direct condition). In this part, the t-test is centred around the relapse coefficients as it were. So, the $t$ test being referred to is the relapse coefficient test. The arrangements utilized are on the off chance that the likelihood esteem is under 0.05 then $\mathrm{H} 0$ is dismissed, or the relapse coefficient is critical, and assuming the likelihood esteem is more prominent than 0.05 then $\mathrm{H} 0$ is acknowledged, or the relapse coefficient isn't huge. Halfway t-test is finished by setting the condition $=\mathrm{a}+\mathrm{b} 1 \mathrm{X} 1+\mathrm{b} 2 \mathrm{X} 2+\mathrm{e}$. The aftereffects of the computation utilizing SPSS are as follows: 
The Effect of Public Accountability and Transparency on State Financial Management Mechanism: A

Table 1.

Regression Coefficient of Variable X Against Variable Y

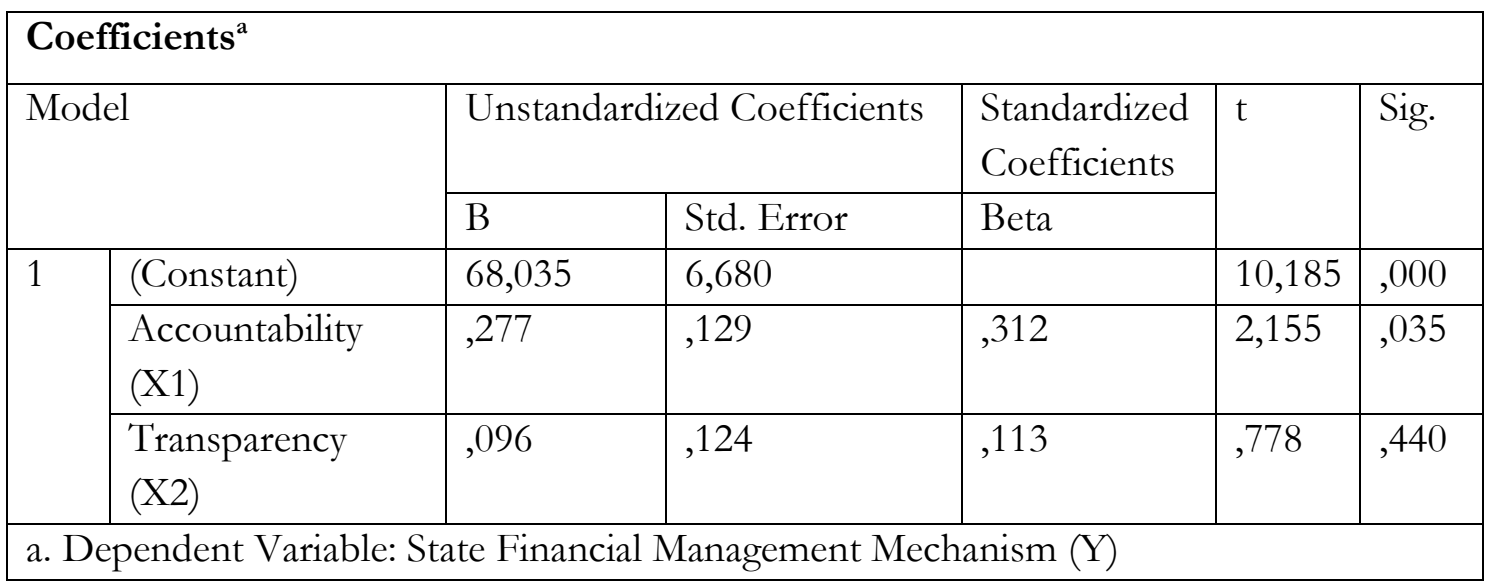

Source: Processed Research Data (2021)

\section{Analysis of the Effect of Variable X on Y Partially}

Based on the data analysis in the table 1, the regression coefficient value of the $\mathrm{X} 1$ variable ( $\mathrm{t}$ count) is 2.155 with a $t$ table of 1.672 , the significance of the Public Accountability variable (X1) on the Financial Management Mechanism (Y) is 0.035 or smaller than the alpha value of 0,05 . In conclusion, the value of $\mathrm{t}$ arithmetic $\mathrm{t}$ table and significance $0.035<0.05$ means that the Public Accountability variable (X1) has a significant effect on the Financial Management Mechanism (Y) or $\mathrm{H} 0$ is rejected and $\mathrm{H} 1$ is accepted.

Furthermore, the value of the regression coefficient ( $\mathrm{t}$ arithmetic) for the $\mathrm{X} 2$ variable is 0.778 with a table of 1.672. The significance of the Public Transparency variable (X2) on the Public Financial Management Mechanism (Y) is 0.440 or greater than the alpha value of 0.05 . In conclusion, the value of $\mathrm{t}$ arithmetic $\mathrm{t}$ table and significance of $0.440>0.05$ means that the Public Transparency variable (X2) has no significant effect on the State Financial Management Mechanism (Y) or H0 is accepted and $\mathrm{H} 1$ is rejected.

\section{Simultaneous F Test}

This test is intended to determine whether there is an effect of the independent variable together with the dependent variable. This test is also known as the model feasibility test or more popularly referred to as the simultaneous test model (D'Esposito et al., 2014; Hoeck \& Spann, 2020). This test identifies the estimated regression model is feasible or not. Appropriate here means that the estimated model is suitable to be used to explain the effect of independent variables on the dependent variable (Cherif et al., 2021; Liu et al., 2021).

The provisions that apply are if the prob value. F count (output results are shown in column sig.) is smaller than the error rate (alpha) of 0.05 (which has been determined), then $\mathrm{H} 0$ is rejected or it can be said that the estimated regression model is feasible, whereas if the value of prob. $\mathrm{F}$ count is greater than the error rate of 0.05 , so it can be said that $\mathrm{H} 0$ is accepted if the value of $\mathrm{f}$ arithmetic $\mathrm{f}$ table and significance 0.05 . And $\mathrm{H} 1$ is accepted if the variables $\mathrm{X} 1$, and $\mathrm{X} 2$, together have a value of $f$ arithmetic $f$ table and significance 0.05 . 
The Effect of Public Accountability and Transparency on State Financial Management Mechanism: A

Table 2.

Results of Simultaneous F Test of Variable X Against Variable Y

\begin{tabular}{|l|l|l|l|l|l|l|}
\hline \multicolumn{2}{|l|}{ ANOVA $^{\mathbf{b}}$} \\
\hline Model & $\begin{array}{l}\text { Sum of } \\
\text { Squares }\end{array}$ & Df & $\begin{array}{l}\text { Mean } \\
\text { Square }\end{array}$ & F & Sig. \\
\hline \multirow{3}{*}{1} & Regression & 879,770 & 2 & 439,885 & 4,929 & $.011 \mathrm{a}$ \\
\cline { 2 - 8 } & Residual & 5087,080 & 57 & 89,247 & & \\
\cline { 2 - 7 } & Total & 5966,850 & 59 & & & \\
\hline
\end{tabular}

Source: Processed Research Data (2021)

\section{Simultaneous Analysis of the Effect of Variable X on Variable $\mathbf{Y}$}

Based on the analysis of the data in the table 2, the $F$ value is 4.929 the $\mathrm{f}$ table value is 3.16 and the significance is 0.011 that is greater than 0.05 , so that $\mathrm{H} 0$ is rejected and $\mathrm{H} 1$ is accepted. It can be concluded that simultaneously the variables X1, and X2 have a significant effect on the variable State Financial Management Mechanism $\left(\mathrm{Y}_{1}\right)$.

\section{R Square Test}

This test is intended to measure how far the independent variable affects the dependent variable.

Table 3.

R Square Test Results Variable X Against Variable Y

\begin{tabular}{|l|l|l|l|l|l|}
\hline \multicolumn{5}{|l|}{ Model Summary } \\
\hline Model & R & R Square & $\begin{array}{l}\text { Adjusted R } \\
\text { Square }\end{array}$ & $\begin{array}{l}\text { Std. Error of } \\
\text { the Estimate }\end{array}$ & $\begin{array}{l}\text { Durbin- } \\
\text { Watson }\end{array}$ \\
\hline 1 & $.852^{\mathrm{a}}$ &, 726 &, 723 & 2,482 & 1,959 \\
\hline \multicolumn{5}{|l|}{ a. Predictors: (Constant), Accountability (X1), Transparancy (X2) } \\
\hline
\end{tabular}

Source: Processed Research Data (2021)

According to table 3, the R-Square value of 0.147 indicates that the proportion of the influence of variable $\mathrm{X}$ on variable $\mathrm{Y}$ is $14.7 \%$. This means that Public Accounting and Transparency have a proportion of influence on the State Financial Management Mechanism of 14.7\% while the remaining $75.3 \%$ is influenced by other variables that are not in this multiple linear regression model.

Based on the analysis above, the results indicate that the aspect of public accountability has a significant influence on the mechanism for managing state finances. These findings suggest the demand for shared-knowledge and open information that meets administrative standard in the financial mechanism to multi stakeholders and the entire decision making, and implementation process has a significant effect in the government's efforts to increase public trust and legitimacy (Esien, 2020a, 2019b) (Shafritz \& Russel, 1997). In addition, the decision-making process in the financial mechanism must be accuracy and fulfil complete ways to achieve policy measures and 
programs goals. Despite standardize writing and openness to the public, accountability also requires data accuracy in the form of statistics and well-managed information for decisions (Esien, 20) in the mechanism of state financial management. In addition to being accurate, the data and information must also be adequate and complete so that they can be used as guidelines in efforts to achieve the goals of a program.

The next aspect of accountability is clear communication with the organization about the objectives, actions, and elements of the state financial management mechanism to be achieved (Balanced Scored Card Institute, 2022), either in the form of a Strategic Plan (Renstra) or Road Map (Road Map) for State Financial Management that is valid for at least the next 5 (five) years. With clear goals, all available resources can be focused on achieving these goals, which have been broken down into monthly and annual program targets. The objective aspect relates to the next aspect, namely the feasibility and consistency of the program's goals and objectives. This means that the goals that have been set must be implemented consistently from time to time, in accordance with the goals and objectives of the program. These process must be supported through well-managed information and performance monitoring system to enable public access of information on state financial management mechanisms (Esien, 2021, 2019b).

From the analysis above, it is known that the aspect of public transparency does not have a significant influence on the mechanism for managing state finances. Based on the survey results, it is known that the public's understanding of the transparency aspect in the state financial management mechanism is still minimal. When referring to the transparency theory of Araujo and Tojedo Romero (2016) that the level of transparency is determined by access to information on state financial management mechanisms as measured by the amount of information available in the financial statements of government institutions, both mandatory and voluntary disclosure of information (Araujo \& Tejedo-Romero, 2016). One of the factors that causes public transparency insignificant influence on the state financial management mechanism, is because the government has not fully disclosed information on state financial management mechanisms which infringe transparency in disfavour for public interest. The government only discloses information about the planned revenue and expenditure budget to the public, but financial information from the use of the budget is still difficult to access. Moreover, there are still significant irregularities in the transparency of performance-based budgeting implementation in Indonesia due to the lack of reliable and valid data (Nurman, 2018). These results suggest, the aspect of public transparency may not have a significant influence on the mechanism for managing state finances.

Although the aspect of public transparency does not have a significant influence on the state financial management mechanism regarding the results of the $f$ test. The data shows that the combination of public accountability and transparency together have an influence on the state financial management mechanism. Even though the influence is not significant enough. The reason relies on the $\mathrm{R}$ Square result, which indicates that the proportion of the effect of the variable of public accountability and transparency is only $14.7 \%$. As a matter of fact, there are still other variables of $75.3 \%$ which have a more significant influence on the management of state finances for fiscal decentralisation and good governance 


\section{CONCLUSION}

Based on the results of research and discussion of research on the effect of public accountability and transparency on the state financial management mechanism, it can be concluded that Public Accountability partially has a significant effect on the Financial Management Mechanism. On the other hand, partially public transparency has no significant effect on the State Financial Management Mechanism. However, simultaneously aspects of Public Accountability and Transparency have a significant effect on the State Financial Management Mechanism. Furthermore, it was concluded that Public Accounting and Transparency had a proportion of influence on the State Financial Management Mechanism of $14.7 \%$ while the remaining $75.3 \%$ was influenced by other variables not examined in the research regarding the effect of public accountability and transparency on the state financial management mechanism. More research and innovation are needed to understand the other variables that influence accountability and transparency in State Financial Management policy arena for fiscal decentralisation and good governance to meets citizens needs. Finding the balance to uphold accountability and transparency in public affairs maybe supportive to citizens aspiration, human values, and dignity to enhance a cohesive society, democracy, and sustainable finance in times of crisis-related society (Esien, 2019a).

\section{REFERENCES}

Adensamer, A., Gsenger, R., \& Klausner, L. D. (2021). “Computer says no”: Algorithmic decision support and organisational responsibility. Journal of Responsible Technology, 7-8, 100014. https://doi.org/10.1016/j.jrt.2021.100014

Alizar, A. M., \& Usman, Y. (2020). Akuntabilitas Penanganan Covid-19. International Association of Public Participation. https://iap2.or.id/akuntabilitas-penanganan-covid-19/

Alom, M. M. (2021). A Closer Look at Organizational Culture in Action (S. Davut Göker (ed.); 1st ed.). IntechOpen. https://doi.org/10.5772/intechopen.77624

Araujo, J. F. F. E. de, \& Tejedo-Romero, F. (2016). Local government transparency index: determinants of municipalities' rankings. International Journal of Public Sector Management, 29(4), 327-347. https://doi.org/10.1108/IJPSM-11-2015-0199

Ayuningtyas, D., Haq, H. U., Utami, R. R. M., \& Susilia, S. (2021). Requestioning the Indonesia Government's Public Policy Response to the COVID-19 Pandemic: Black Box Analysis for the Period of January-July 2020. Frontiers in Public Health, 9. https://doi.org/10.3389/fpubh.2021.612994

Benites-Lazaro, L. L., Giatti, L., \& Giarolla, A. (2018). Sustainability and governance of sugarcane ethanol companies in Brazil: Topic modeling analysis of CSR reporting. Journal of Cleaner Production, 197, 583-591. https://doi.org/10.1016/j.jclepro.2018.06.212

Carías Vega, D. E., \& Keenan, R. J. (2016). Situating community forestry enterprises within New Institutional Economic theory: What are the implications for their organization? Journal of Forest Economics, 25, 1-13. https://doi.org/10.1016/j.jfe.2016.07.001

Chatzivgeri, E., Chew, L., Crawford, L., Gordon, M., \& Haslam, J. (2020). Transparency and accountability for the global good? The UK's implementation of EU law requiring countryby-country reporting of payments to governments by extractives. Critical Perspectives on Accounting, 67-68, 102074. https://doi.org/10.1016/j.cpa.2019.02.001 
The Effect of Public Accountability and Transparency on State Financial Management Mechanism: A

Cherif, E., Bezaz, N., \& Mzoughi, M. (2021). Do personal health concerns and trust in healthcare providers mitigate privacy concerns? Effects on patients' intention to share personal health data on electronic health records. Social Science \& Medicine, 283, 114146. https://doi.org/10.1016/j.socscimed.2021.114146

D’Esposito, M. R., De Stefano, D., \& Ragozini, G. (2014). On the use of Multiple Correspondence Analysis to visually explore affiliation networks. Social Networks, 38, 28-40. https://doi.org/10.1016/j.socnet.2014.01.003

de Renzio, P. (2015). Transparency and participation in public financial management. GSDRC Applied Knowledge Series. https://gsdrc.org/professional-dev/transparency-and-participation-inpublic-financial-management/

Deegan, C., \& Islam, M. A. (2014). An exploration of NGO and media efforts to influence workplace practices and associated accountability within global supply chains. The British Accounting Review, 46(4), 397-415. https://doi.org/10.1016/j.bar.2014.10.002

Desselle, S. P., Raja, L., Andrews, B., \& Lui, J. (2018). Perceptions of organizational culture and organizational citizenship by faculty in U.S. colleges and schools of pharmacy. Currents in Pharmacy Teaching and Learning, 10(4), 403-412. https://doi.org/10.1016/j.cptl.2017.12.017

Elgebeily, E., Guermat, C., \& Vendrame, V. (2021). Managerial optimism and investment decision in the UK. Journal of Behavioral and Experimental Finance, 31, 100519. https://doi.org/10.1016/j.jbef.2021.100519

Esien, E. B. (2019a). Principal-Agent Relation and Contracting-out for Employment Case Management to Enable Third-Country Nationals' Transition to Work. NISP Acee Journal of Public Administration and Policy, 12(2), 9-28. https://doi.org/10.2478/nispa-2019-0012

Esien, E. B. (2020a). Open Information, Contract Management, Transparency and Ethical Standards: In Local Government Units Contracting Out for Case Management Service Delivery. In D. V. M., J. Nemec, \& V. Junjan (Eds.), The Choice-Architecture bebind Policy Designs: From Policy Design to Policy Practice in the European Integration Context (1st ed., pp. 267 281). NISPACee Press.

https://ris.utwente.nl/ws/portalfiles/portal/175963587/21_31_from_PRACTIC_monogr aph_final.pdf

Esien, E. B. (2020b). Decision Making, Interest Intermediation, and Value: In Government, Public, and Private Agencies Corporatism for Work Promotion. DANUBE, 11(4), 324 342. https://doi.org/10.2478/danb-2020-0019

Esien, E. B. (2021). Enabling State and Unemployed Third-country Nationals: In local government and Private Agencies Contracting for Counselling. Kariérové Poradenstvo v Teórii a Praxi, 9(1), 21-43.

https:/ /is.cuni.cz/studium/predmety/index.php?do=predmet\&kod=JSM709

Esien, E. B. (2019b). Activation and Unemployed Third-country Nationals: The Implication of Work-related incentives to promote work in Austria, Finland, and Czech Republic. In V. Napoleva (Ed.), Proceedings of International Scientific Conference (pp. 167-180). Vysoka Skola PRIGO. https://www.narodacek.cz/wp-content/uploads/2019/12/Proceedings-of-theInternational-Scientific-Conference_2019-179-192.pdf

European Commission. (2017). Quality of Public Administration: A Toolbox for Practitioners (F. Hauser (ed.); 1st ed.). Publications Office of the European Union. https://doi.org/10.2767/483489

Gonçalves, S. M., da Silva, R. V., \& Teixeira, N. (2019). Individual actors and embeddedness in 
The Effect of Public Accountability and Transparency on State Financial Management Mechanism: A

business-to-business interactions. Industrial Marketing Management, 76, 181-191. https://doi.org/10.1016/j.indmarman.2018.08.006

Hayes, A. (2022). Multiple Linear Regression (MLR). Investopedia. https://www.investopedia.com/terms/m/mlr.asp

Hoeck, L., \& Spann, M. (2020). An Experimental Analysis of the Effectiveness of Multi-Screen Advertising. Journal of Interactive Marketing, 50, 81-99. https://doi.org/10.1016/j.intmar.2020.01.002

Holly, C. (2014). Scholarly Inquiry and the DNP Capstone. Springer Publishing Company. https://doi.org/10.1891/9780826193889

Ismail, F., \& Clarke, S. P. (2014). Improving the Employer-Regulator Partnership: An Analysis of Employer Engagement in Discipline Monitoring. Journal of Nursing Regulation, 5(3), 19-23. https://doi.org/10.1016/S2155-8256(15)30056-9

Jansen, D., \& Warren, K. (2020). Quantitative Data Analysis 101: The lingo, methods and techniques, explained simply. Gradcoach. https://gradcoach.com/quantitative-data-analysis-methods/

Keevill, L. (2020). We're Still Open: Balancing government transparency and accountability with effective crisis response. Pactworld. https://www.pactworld.org/blog/'we're-still-open'-balancinggovernment-transparency-and-accountability-effective-crisis

Kesberg, R., \& Keller, J. (2021). Donating to the 'right' cause: Compatibility of personal values and mission statements of philanthropic organizations fosters prosocial behavior. Personality and Individual Differences, 168, 110313. https://doi.org/10.1016/j.paid.2020.110313

Khotami, M. (2017). The Concept Of Accountability In Good Governance. Proceedings of the International Conference on Democracy, Accountability and Governance (ICODAG 2017). https://doi.org/10.2991/icodag-17.2017.6

Krejcie, R. V., \& Morgan, D. W. (1970). Determining Sample Size for Research Activities. Educational and Psychological Measurement, 30(3), 607-610. https://doi.org/10.1177/001316447003000308

Krejcie, R. V., \& Morgan, D. W. (2017). Krejcie and Morgan Sampling Method. Quantitative Research Design. http://in-troh-spective.blogspot.com/2017/10/krejcie-and-morgan-samplingmethod.html

Liu, X. L., Lu, J. G., Zhang, H., \& Cai, Y. (2021). Helping the organization but hurting yourself: How employees' unethical pro-organizational behavior predicts work-to-life conflict. Organizational Behavior and Human Decision Processes, 167, 88-100. https://doi.org/10.1016/j.obhdp.2021.05.002

Low, K. Y. J., \& Ho, E. Y.-C. (2016). A Knowledge-based Theory of the Multinational Economic Organization. Long Range Planning, 49(6), 641-647. https://doi.org/10.1016/j.lrp.2015.12.004

Lysova, E. I., Allan, B. A., Dik, B. J., Duffy, R. D., \& Steger, M. F. (2019). Fostering meaningful work in organizations: A multi-level review and integration. Journal of Vocational Behavior, 110, 374-389. https://doi.org/10.1016/j.jvb.2018.07.004

Mardiasmo. (2018). Otonomi Dan Manajemen Keuangan Daerah (Mardiasmo (ed.); III). Penerbit ANDI. https:/ / andipublisher.com/produk-otonomi-dan-manajemen-keuangan-daerahedisi-terbaru

Martini, M. (2012). Causes of corruption in Indonesia. https://knowledgehub.transparency.org/assets/uploads/helpdesk/338_Causes_of_corrupt 
The Effect of Public Accountability and Transparency on State Financial Management Mechanism: A

ion_in_Indonesia.pdf

Monfort, A., Villagra, N., \& Sánchez, J. (2021). Economic impact of corporate foundations: An event analysis approach. Journal of Business Research, 122, 159-170. https://doi.org/10.1016/j.jbusres.2020.08.046

Morgan, N. A., Jayachandran, S., Hulland, J., Kumar, B., Katsikeas, C., \& Somosi, A. (2021). Marketing performance assessment and accountability: Process and outcomes. International Journal of Research in Marketing. https://doi.org/10.1016/j.ijresmar.2021.10.008

Nielsen, J., Eckstein, L., Nicol, D., \& Stewart, C. (2021). Integrating Public Participation, Transparency and Accountability Into Governance of Marketing Authorisation for Genome Editing Products. Frontiers in Political Science, 3. https://doi.org/10.3389/fpos.2021.747838

Noels, J. (2018). What Is SPSS and its Important in Research \& Data Analysis. Medium. https://johnnoels.medium.com/what-is-spss-and-its-importance-in-research-data-analysis5f109ab90da1\#: :text=SPSS (Statistical package for the,surveys $\% 2 \mathrm{C}$ data mining $\% 2 \mathrm{C}$ etc.

Nurman, A. (2018). Program Budgeting in the Health Sector in Indonesia. https:/ / inisiatif.org/?p=12836\&lang=en

Parsa, S., Roper, I., Muller-Camen, M., \& Szigetvari, E. (2018). Have labour practices and human rights disclosures enhanced corporate accountability? The case of the GRI framework. Accounting Forum, 42(1), 47-64. https://doi.org/10.1016/j.accfor.2018.01.001

Pinha, A. C. H., \& Sagawa, J. K. (2020). A system dynamics modelling approach for municipal solid waste management and financial analysis. Journal of Cleaner Production, 269, 122350. https://doi.org/10.1016/j.jclepro.2020.122350

Rahaman, M. M. (2014). Do managerial behaviors trigger firm exit? The case of hyperactive bidders. The Quarterly Review of Economics and Finance, 54(1), 92-110. https://doi.org/10.1016/j.qref.2013.09.001

Robinson, M. (2015). From Old Public Administration to the New Public Service: Implications for Public Sector Reform in Developing Countries (No. 08; Global Centre for Public Service Excellence). https://www.undp.org/publications/old-public-administration-new-public-service

Robinson, S. C. (2020). Trust, transparency, and openness: How inclusion of cultural values shapes Nordic national public policy strategies for artificial intelligence (AI). Technology in Society, 63, 101421. https://doi.org/10.1016/j.techsoc.2020.101421

Sawandi, N., \& Thomson, I. (2014). Broadening Corporate Accountability: An 'Idealised' Downward Accountability Model. Procedia - Social and Behavioral Sciences, 164, 429-436. https://doi.org/10.1016/j.sbspro.2014.11.099

Shnayder, L., van Rijnsoever, F. J., \& Hekkert, M. P. (2016). Motivations for Corporate Social Responsibility in the packaged food industry: an institutional and stakeholder management perspective. Journal of Cleaner Production, 122, 212-227. https://doi.org/10.1016/j.jclepro.2016.02.030

Varga, S., Brynielsson, J., \& Franke, U. (2021). Cyber-threat perception and risk management in the Swedish financial sector. Computers \& Security, 105, 102239. https://doi.org/10.1016/j.cose.2021.102239

Wibisono, Y. (2017). Membedah Konsep dan Aplikasi CSR (Corporate Social Responsibility) (2nd ed.). Fasch Publishing. http://ailis.lib.unair.ac.id/opac/detail-opac?id=60263 